\title{
POLYGALA PETRICOLA (POLYGALACEAE), A NEW SPECIES FROM BRAZIL
}

\author{
J. F. B. Pastore ${ }^{1}$, S. S. Flaviano ${ }^{2}$, M. O. D. Pivari ${ }^{3}$, A. C. S. A. Anastacio ${ }^{4} \&$ \\ E. Amano ${ }^{5}$
}

Polygala petricola, a new species from Brazil, is described. It belongs to the subgenus Polygala, sect. Timutua, ser. Eriocoideae. The diagnostic characters distinguishing it from its closest relatives are described and discussed. Its conservation status is assessed, and a distribution map and illustrations are provided.

Keywords. Brazilian flora, endemic, new species, sect. Timutua, ser. Ericoideae, subgen. Polygala, taxonomy.

Received 10 July 2019 Accepted 9 December 2020 Published 14 April 2021

\section{Introduction}

Polygala L., the most diverse genus in the family Polygalaceae, with c.580 species of herbs to subshrubs (Pastore, 2018), is represented in Brazil by 107 species (of the sections Clinclinia DC. and Timutua DC.) occurring in all its biomes but mostly in the savanna regions. Most species of Polygala in Brazil belong to the section Timutua, which is divided into a number of series. Although it has recently been shown that most of these series are not monophyletic (Pastore et al., 2019), a new taxonomic treatment has yet to be proposed. Nonetheless, the series Ericoideae Chodat of sect. Timutua is monophyletic and easily recognised by its morphology (Marques, 1988; Pastore et al., 2019). Members are characterised by the usual presence of xylopodia, short racemes, small yellow spots on the floral parts, and an erect style (Marques, 1988).

During extensive fieldwork and analyses of herbarium specimens, we found an undescribed species of ser. Ericoideae from the region of the Serra da Moeda (Minas Gerais state, Brazil). This new species is here described and illustrated by photographs, including of details of the floral parts, accompanied by comparisons with allied species.

\footnotetext{
${ }^{1}$ Herbarium CTBS, Universidade Federal de Santa Catarina, Campus de Curitibanos, Rodovia Ulysses Gaboardi, km 3, Curitibanos, Santa Catarina, Brazil. E-mail: jfpastore@hotmail.com.

2 Programa de Pós-Graduação em Botânica da Universidade Federal do Paraná, Avenida Cel. Francisco H. dos Santos, s.n., Campus do Centro Politécnico, Curitiba, Paraná, Brazil.

${ }^{3}$ Bioma Meio Ambiente, Alameda do Ingá, $840,10^{\circ}$ Andar, Vale do Sereno, Nova Lima, Minas Gerais, Brazil.

${ }^{4}$ Vale, Mina de Águas Claras, Avenida Dr Marco Paulo Simon Jardim, 3580 - Vila da Serra, Nova Lima, Minas Gerais, Brazil.

${ }^{5}$ Departamento de Botânica, Universidade Federal do Paraná, Avenida Cel. Francisco H. dos Santos, s.n., Campus do Centro Politécnico, Curitiba, Paraná, Brazil.
} 


\section{Taxonomic treatment}

Polygala L. sect. Timutua DC. ser. Ericoideae Chodat, Mém. Soc. Phys. Genève 31(2, 2): 126 (and 239) (1893).

The series Ericoideae consists of 17 species, all endemic to Brazil except for Polygala obovata A.St.-Hil. \& Moq. and $P$. regnellii Chodat, which are additionally found in Paraguay and Bolivia, respectively. They occur in rocky to savanic vegetation, and are often adapted to seasonal fires.

\section{Polygala petricola J.F.B.Pastore, sp. nov.}

Resembling Polygala rigida A.St.-Hil. \& Moq. in its yellowish flowers in short racemes and linear leaves, but easily distinguished from that species by its chartaceous leaves (versus leather-like), flower parts that are generally smaller and differently shaped (Figure 1), bracts that are a little longer than the bracteoles (versus more than twice as long), internal sepals having a number of yellow spots close to the central nerve (versus without yellow spots), the base of the style being almost $1 / 2$ the length of the style (versus a very short base, less than $1 / 5$ of the style length), a keel with a few yellow spots close to the central vein dorsally and with short crest lobes, the central lobe c. $1 \mathrm{~mm}$ long (versus a keel with several yellow spots close to the central vein dorsally and long crest lobes, the central lobe c. $2 \mathrm{~mm}$ long). - Type: Brazil, Minas Gerais, Brumadinho, Fazenda Cachoeira, $1158 \mathrm{~m}$ altitude, $20^{\circ} 05^{\prime} 49^{\prime \prime S}, 44^{\circ} 01^{\prime} 19^{\prime \prime} W, 29$ i 2018, Paiva, J.A.M., Souza, J.A.M. \& Silva, S.H.A. 1632 (holotype CTBS, isotype BHCB). Figures 2, 3.

Erect subshrub, 20-35 cm tall, roots rigid, few to many stems arising from the base, stem sparsely branched at the apex, cylindrical, striated, densely puberulous, trichomes short-clavate, stems green, without yellowish glands forming spots. Leaves all alternate, subsessile, chartaceous, lamina (8-)11-14 × (0.8-)1.1-1.9 mm, linear to linear-elliptical, apex acute, margin revolute, base acute, densely covered by short glandular trichomes. Racemes congested $0.8-1.2 \times 0.9-1.1 \mathrm{~cm}, 4.5 \mathrm{~cm}$ counting the part of the floral stem with the scars of the fruits fallen; bracts c. $1 \times 0.7 \mathrm{~mm}$, lanceolate, apex acute, ciliate, trichomes glandular, with one or two yellowish spots at the base, deciduous before opening of flowers, c.1.1 times longer than bracteoles; bracteoles lanceolate, ciliate, trichomes glandular; pedicel 3.3-3.4 mm, puberulous, trichomes glandular. Flowers yellowish, 4.4-5.1 mm long (without pedicel); outer sepals ciliate, trichomes glandular, with yellow spots along the central vein; lower outer sepals 1.7-1.8 $\times 0.8 \mathrm{~mm}$, ovate, apex acute; upper outer sepals $2.2 \times$ $1.1 \mathrm{~mm}$, elliptic, apex acute; inner sepals (wings) $3.6 \times 1.7 \mathrm{~mm}$, elliptic, apex acute, margins sparsely ciliate at base, longer than mature fruits, with yellow spots along the central vein; lateral petals $3.1 \times 1 \mathrm{~mm}$, with one yellow spot; keel c.3.4-3.6 mm long, cristate, with yellow spots around the dorsal central vein, persistent in mature fruits; crest 4- to 6-lobed; central lobes c. $1 \mathrm{~mm}$, not lobed to apex; style c. $1 \mathrm{~mm}$, inclined, terminated by an oblique 


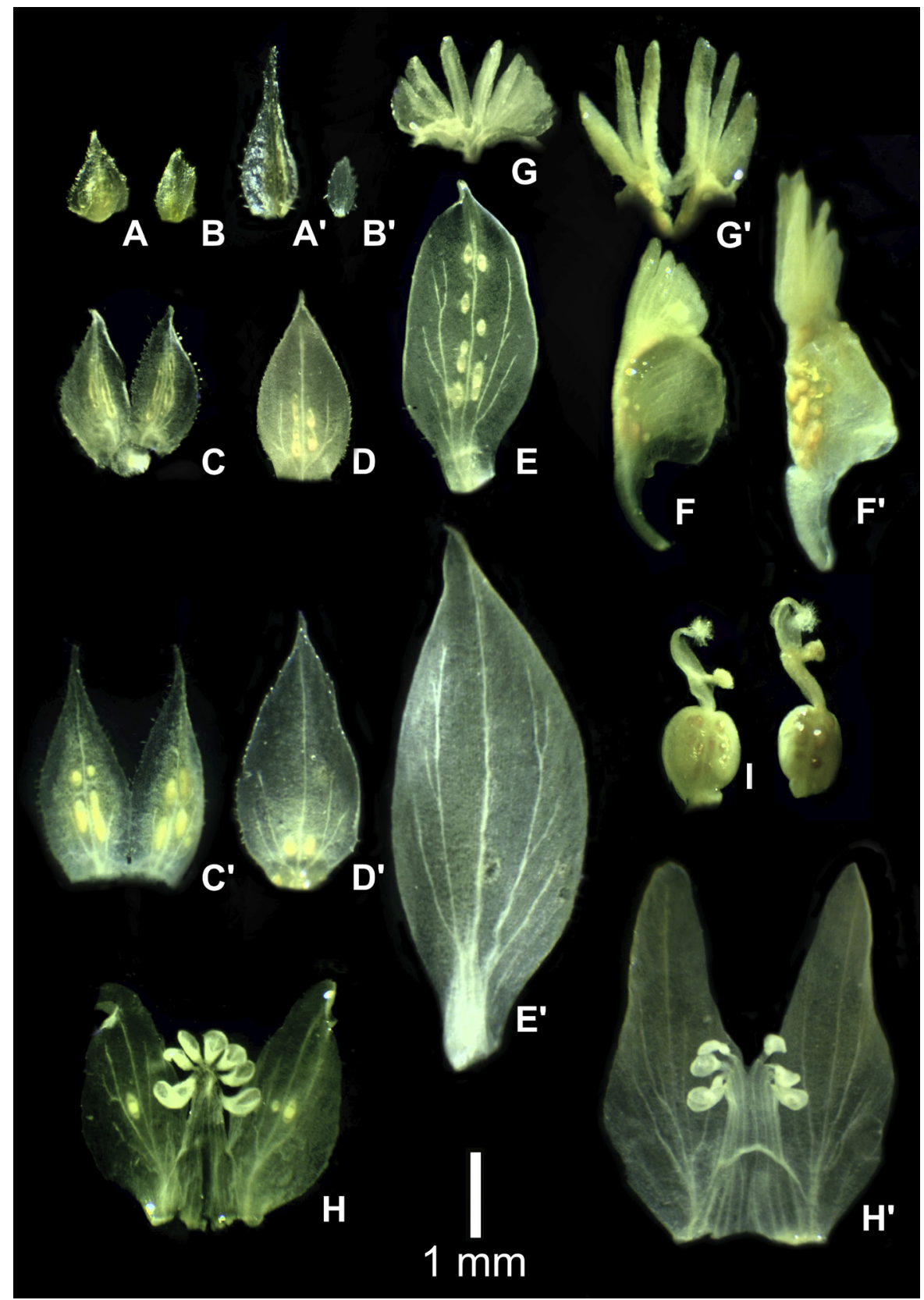

Figure 1. Comparison of the floral details of Polygala petricola J.F.B.Pastore, sp. nov., and P. rigida A.St.Hil. \& Moq. A and A', Bract; B and B', bracteole; $C$ and $C^{\prime}$, two superior outer sepals; D and D', inferior outer sepal; $E$ and $E^{\prime}$, one of the two inner sepals (wings); $F$ and $F^{\prime}$, keel; $G$ and $G^{\prime}$, opened crest; $H$ and $\mathrm{H}^{\prime}$, androecium and lateral petals; I and I', gynoecium. A-I, Polygala petricola (Paiva et al. 1632, CTBS). A'-I', Polygala rigida (Oliveira et al. 6161, CTBS). Photographs by J. F. B. Pastore. 


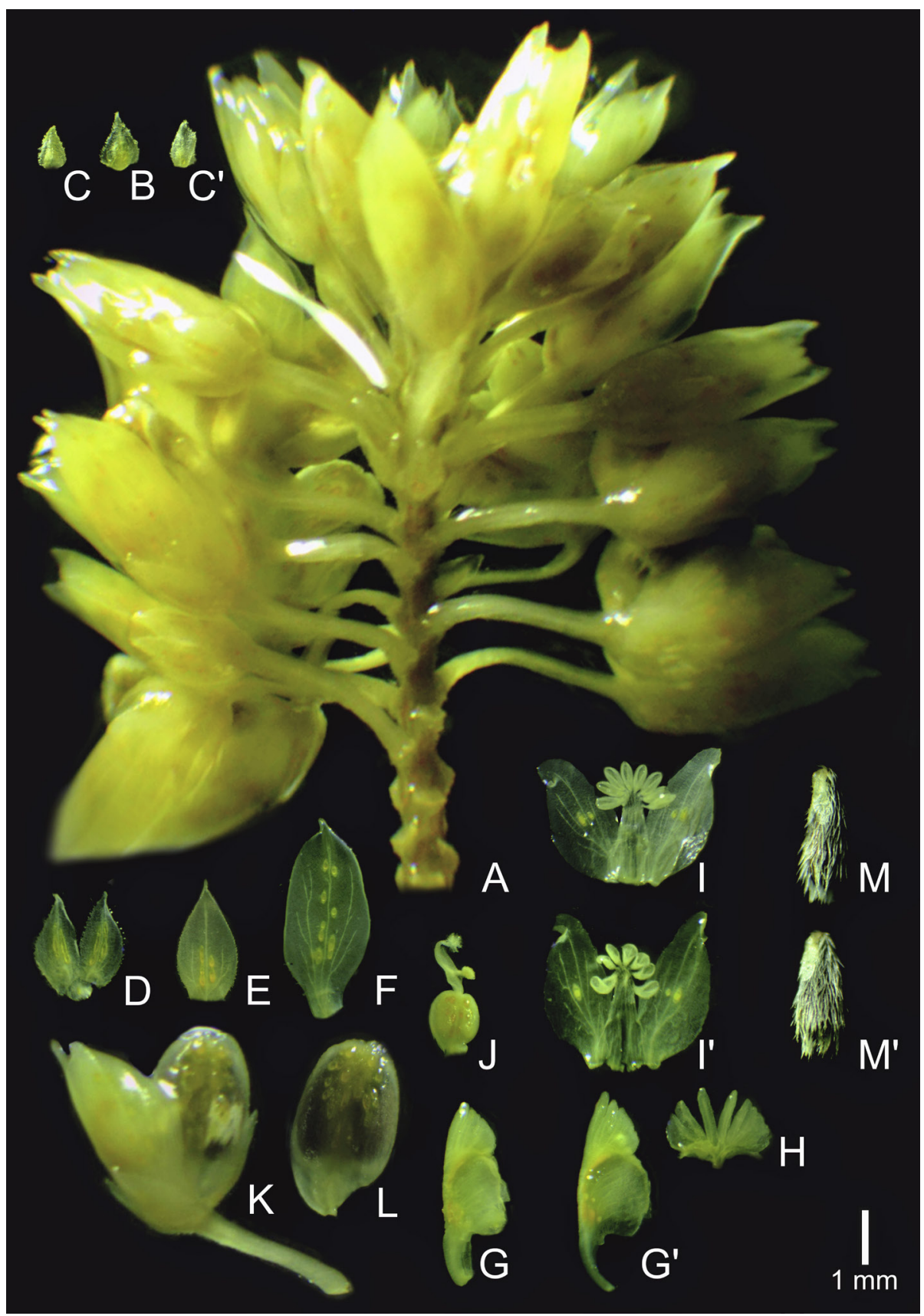

Figure 2. Polygala petricola J.F.B.Pastore, sp. nov. A, Raceme; B, bract; C and C', bracteoles; D, two superior outer sepals; $E$, inferior outer sepal; $F$, one of the two inner sepals (wings); $G$ and $G$ ', keel; $\mathrm{H}$, opened crest; I and I', androecium and lateral petals; J, gynoecium; $\mathrm{K}$, fruiting calyx; L, capsule; $M$ and M', seed (scale bar, $1 \mathrm{~mm}$ ). All from Paiva et al. 1632 (CTBS). Photographs by J. F. B. Pastore. 


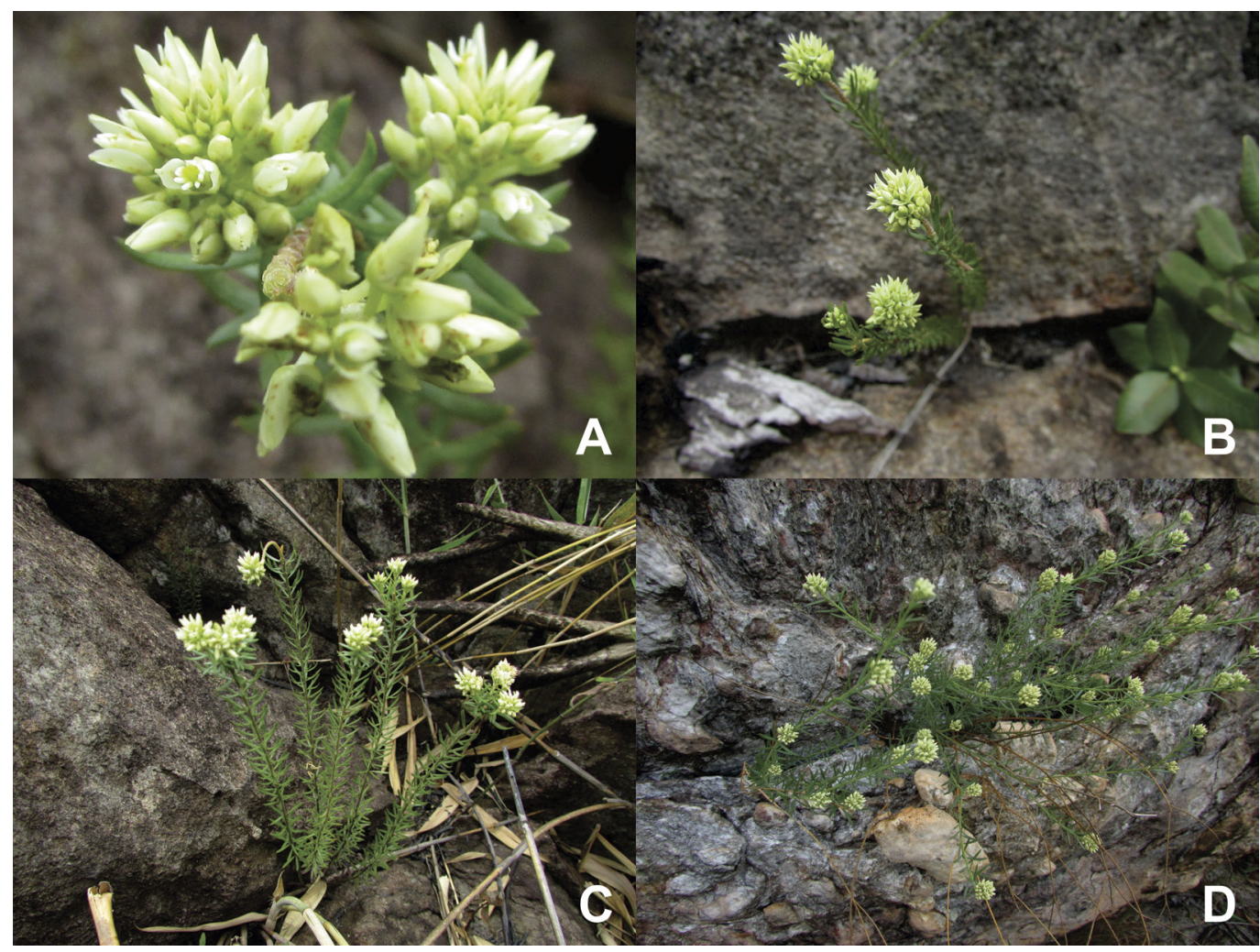

Figure 3. Polygala petricola J.F.B.Pastore, sp. nov. A, Flowers and racemes; B-D, plant and habitat. Photographs: A-C, Souza et al. 144 (CTBS); D, Paiva et al. 1632 (CTBS). Photographs: A.-C. J. A. M. Souza and D. J. A. M. Paiva.

cymbiform prestigmatic cavity, posterior extremity with a conspicuously crested appendage with abundant trichomes and an anterior globose stigma. Capsules $3.2 \times 1.7-1.8 \mathrm{~mm}$, subelliptical, with several yellow spots close to the central nerve, style caducous in fruit; seeds c.2.1-2.2 $\times 0.8 \mathrm{~mm}$, subconical, pubescent, trichomes $0.3 \mathrm{~mm}$, with caruncular appendages $1 \times 0.3 \mathrm{~mm}$ to $\mathrm{c} .1 / 3$ of the seed length.

Distribution. The new species was collected on Serra da Moeda in the municipality of Brumadinho, Minas Gerais, near the Casa Branca District in the western part of Brumadinho, close to the municipality of Nova Lima (Figure 4).

Habitat and ecology. Above $1100 \mathrm{~m}$ a.s.l., occurring in campo rupestre vegetation on sandy soils with rocks, on the southeast slopes of Serra da Moeda.

Flowering. The new species was collected with flowers and fruits in January, February, October and November. 


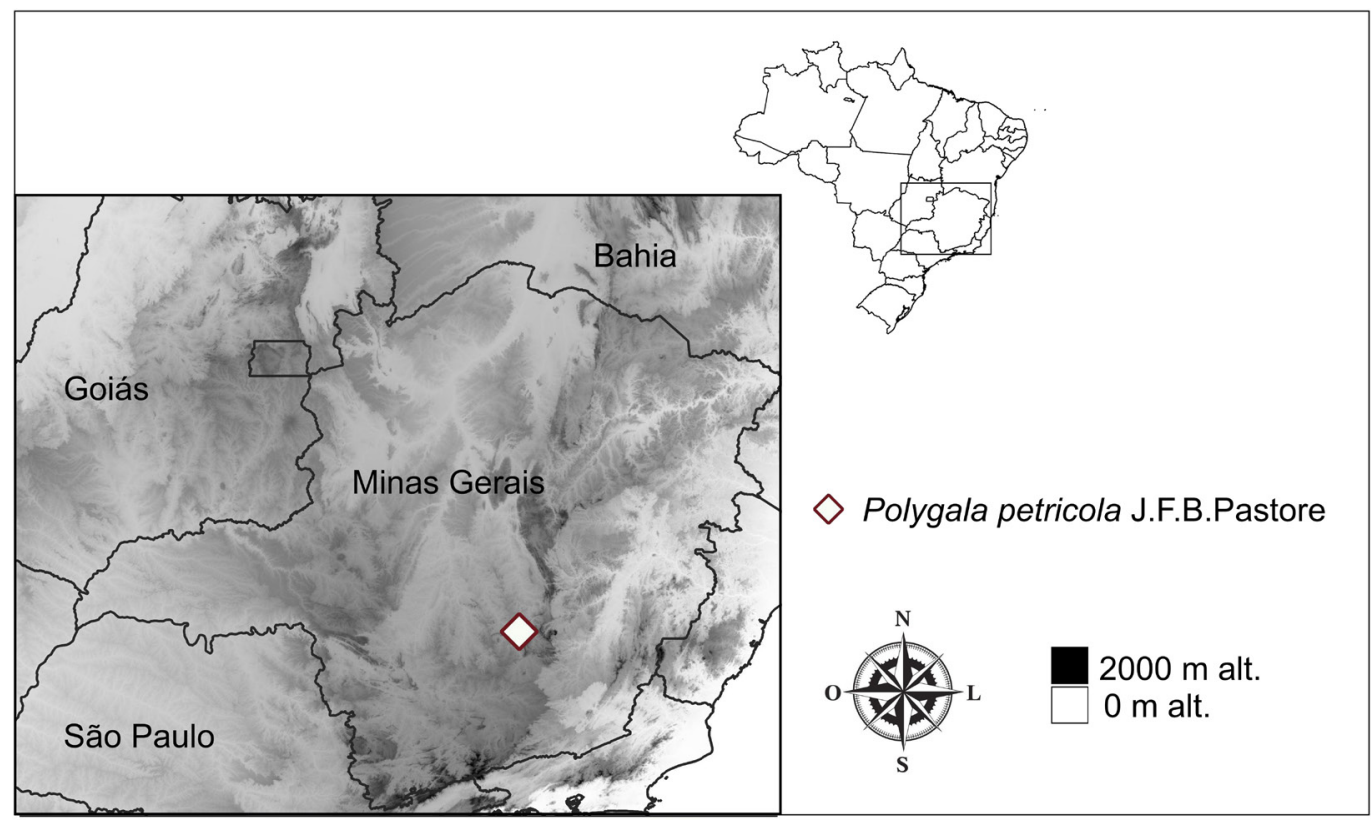

Figure 4. Distribution of Polygala petricola J.F.B.Pastore, sp. nov.

Etymology. The epithet of Polygala petricola refers to its preference for rocky habitats.

Provisional IUCN conservation assessment. The only known specimens were collected within or near the area of Serra da Moeda. Two of these were collected in a legal reserve area. The extent of occurrence (EOO) and area of occupancy (AOO) were calculated using the online software GeoCat (Bachman, 2011), resulting in $4 \mathrm{~km}^{2}$ for the EOO and an AOO of $12 \mathrm{~km}^{2}$. The IUCN assessment according to the criteria B: B1 and B2 a, b(iii) (IUCN, 2012) is Critically Endangered (CR). Polygala petricola also falls within the criterion b-III of the IUCN (2012), because the region is subjected to mining activity disturbances and urban sprawl.

Additional specimens examined. BRAZIL. Minas Gerais: Brumadinho, Serra da calçada, Retiro das

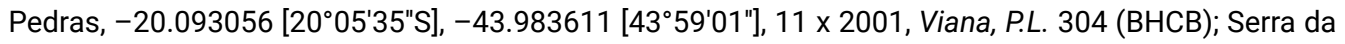
Moeda, 2006'54"S, 4359'29"W, $1417 \mathrm{~m}$ alt., 7 xi 2107, Souza, J.A.M. et al. 144 (BHCB); ibid., Serra da Moeda, 20 ii 1990, Porto-Paula, L.M. \& Grandi, T.S.M. 886 (BHZB, CTBS).

\section{Acknowledgements}

The authors are grateful to the curatorial staff of the Herbário da Universidade Federal de Minas Gerais (BHCB) for providing access to their collections; to Michelle Mota for preparing the distribution map; to Vale S.A. for granting access to their particular areas for collections and for funding the research that made these collections possible. J.F.B.P. gratefully acknowledges funding for a research fellowship (302452/2017-6) from the CNPq (Conselho Nacional de Desenvolvimento Científico e Tecnológico). 


\section{References}

Bachman S, Moat J, Hill AW, de la Torre J, Scott B. 2011. Supporting Red List threat assessments with GeoCAT: Geospatial Conservation Assessment Tool. In: Smith V, Penev L, editors. E-Infrastructures for Data Publishing in Biodiversity Science. ZooKeys. 150:117-126 (version BETA). http://geocat. kew.org/

IUCN. 2012. IUCN Red List Categories and Criteria, version 3.1, 2nd edition. Gland, Switzerland, and Cambridge: International Union for Conservation of Nature.

Marques MCM. 1988. Polígalas do Brasil - V. Seção Polygala (Polygalaceae). Archivos (Arquivos) do Jardim Botânico do Rio de Janeiro. 29:1-114.

Pastore JFB. 2018. Polygala veadeiroensis (Polygalaceae), a new species of Polygala endemic to Chapada dos Veadeiros, Goiás, Brazil. Kew Bulletin. 73(3):37-39.

Pastore JFB, Abbott JR, Neubig K, Van Den Berg C, Mota MCA, Cabral A, Whitten WM. 2019. Phylogeny and biogeography of Polygala (Polygalaceae). Taxon. 68(4):673-691. 